\title{
Acquired colour vision deficiency in patients receiving digoxin maintenance therapy
}

\author{
J G Lawrenson, C Kelly, A L Lawrenson, J Birch
}

Br J Ophthalmol 2002;86:1259-1261

Background/aims: Disturbances of colour vision are a frequently reported sign of digoxin toxicity. The aim of this study was to investigate the incidence of acquired colour vision deficiency in elderly hospitalised patients receiving maintenance digoxin therapy.

Methods: 30 patients (mean age 81.3 (SD 6.1) years) receiving digoxin were tested using a battery of colour vision tests (Ishihara, AO Hardy Rand Rittler plates, City tritan test, Lanthony tritan album, and the Farnsworth D15). These were compared to an age matched control group. Serum digoxin concentrations were determined from venous blood samples.

Results: Slight to moderate red-green impairment was found in approximately $20-30 \%$ of patients taking digitalis, and approximately $20 \%$ showed a severe tritan deficiency. There was no correlation between colour vision impairment and serum digoxin level.

Conclusions: Formal colour vision testing of elderly patients taking digitalis showed a high incidence of colour deficiency, suggesting that impairment of retinal function can occur even at therapeutic drug levels. As a result, colour vision testing in this population would have limited value for the detection of drug toxicity.

D igoxin remains a frequently prescribed cardiac glycoside used in the treatment of supraventricular dysrhythmias and congestive cardiac failure. ${ }^{1}$ Cardiac glycosides have a narrow therapeutic index, and there is considerable overlap in serum concentration of the drug between patients with and without toxicity. ${ }^{2}$ Although the clinical diagnosis of digoxin toxicity has fallen substantially over the past $20-30$ years, ${ }^{34}$ it remains a common medical problem, particularly in the elderly, where it is often difficult to diagnose. ${ }^{5}$ Features of digoxin toxicity are usually non-specific and consist of cardiac and non-cardiac effects. Non-cardiac manifestations include symptoms of fatigue, anorexia, nausea, vomiting, headaches, and confusion. Disturbances of vision-for example, blurring, central scotomas, glare effects, and altered colour perception, are a less common but more specific presenting complaint. ${ }^{26}$ Symptomatic colour vision disturbances-for example, xanthopsia, are found in up to $15 \%$ of intoxicated patients, ${ }^{7}$ although formal testing reveals a much higher incidence of colour deficiency. ${ }^{8}$ Impairment in both the tritan and red-green $(\mathrm{R} / \mathrm{G})$ axes have been found. ${ }^{9-12}$ Using the Farnsworth-Munsell (FM) 100 hue test, several studies have reported a strong positive correlation between the total error score and serum digoxin level, suggesting that colour vision assessment may be used as a predictor of toxicity. ${ }^{8}{ }^{11} 13$

The aims of the present study were to use rapid screening tests for tritan and red-green colour defects to investigate the incidence of acquired colour deficiency in a population of elderly patients receiving maintenance digoxin therapy, and fur- thermore, to reassess the relation between serum digoxin concentration and colour vision impairment.

\section{SUBJECTS AND METHODS}

Colour vision was assessed in 30 hospitalised patients (10 males and 20 females, mean age 81.3 (SD 6.1) years) who were receiving oral digoxin maintenance therapy. The daily dose varied from $62.5 \mu \mathrm{g}$ to $250 \mu \mathrm{g}$ (mean 127.1 (44.9) $\mu \mathrm{g}$ ), and the mean duration of treatment was 32.4 (62.8) months. Patients with glaucoma, diabetes, retinal/optic nerve disease, significant cataract, and congenital colour deficiency were excluded, as were patients taking concomitant medication known to affect colour perception. The visual acuity of all subjects was 6/12 or better. A battery of pseudoisochromatic plates and a hue discrimination test were used for colour vision assessment. The tests used and their scoring criteria were as follows:

Ishihara pseudoisochromatic plates (38 plate edition)-Plates 1-17 were used on all patients to identify red-green colour deficiency. Patients with greater than three errors were classified as failing the test.

AO Hardy Rand Rittler (HRR) plates-The HRR test identifies and grades the severity of red-green and tritan defects. The defect can be classified as slight or significant (moderate or severe) depending on the number of errors.

City tritan test-This test has five plates. Three plates have small colour differences, identifying slight tritan defects, and two plates have large colour differences to identify severe tritan deficiency.

Lanthony tritan album-The tritan album has six plates. Severity of tritan deficiency (slight, moderate or severe) is determined by the number of errors.

Farnsworth D15-This hue discrimination arrangement test uses 15 coloured caps which are arranged in sequence from a fixed pilot cap. The results are plotted on a hue circle diagram, which allows tritan defects, red-green defects or generally poor hue discrimination to be identified.

Colour vision testing was carried out in good daylight conditions, supplemented when necessary with artificial lighting. Thirty age matched control subjects (eight males and 22 females, mean age 76.8 (11.5) years), who were also hospital inpatients but were not taking digoxin, were examined with the same test battery. The serum digoxin level was determined by immunoassay on samples of venous blood taken at least 6 hours after the last dose.

\section{RESULTS}

\section{Plate tests}

Subjects receiving digoxin showed a significant number of red-green and tritan colour vision errors (Tables 1 and 2). The Ishihara test identified red-green deficiency in $23.3 \%$ of subjects. A greater number failed the red-green plates of the AO HRR test (20\% with slight defects and $13.3 \%$ showing significant red-green defects). By contrast, no control subject failed the Ishihara or the red-green grading plates of the HRR. 
Table 1 Results of red-green screening tests

\begin{tabular}{llll}
\hline & $\begin{array}{l}\text { HRR red-green plates } \\
\text { \% Fail }\end{array}$ & \% Slight & \% Moderate \\
\cline { 3 - 4 } & 0 & 0 & 0 \\
\hline Controls & 0 & 20 & 13.3 \\
\hline
\end{tabular}

Table 2 Results of tritan screening tests

\begin{tabular}{|c|c|c|c|c|c|c|c|}
\hline & \multicolumn{2}{|c|}{$\begin{array}{l}\text { HRR tritan } \\
\text { plates }\end{array}$} & \multicolumn{2}{|c|}{ City tritan test } & \multicolumn{3}{|c|}{ Lanthony tritan album } \\
\hline & $\begin{array}{l}\% \\
\text { Slight }\end{array}$ & $\begin{array}{l}\% \\
\text { Severe }\end{array}$ & $\begin{array}{l}\% \\
\text { Slight }\end{array}$ & $\begin{array}{l}\% \\
\text { Severe }\end{array}$ & $\begin{array}{l}\% \\
\text { Slight }\end{array}$ & $\begin{array}{l}\% \\
\text { Moderate }\end{array}$ & $\%$ \\
\hline Controls & 30 & 0 & 20 & 0 & 26.7 & 10 & 0 \\
\hline Digoxin & 36.2 & 23.3 & 30 & 20 & 26.7 & 6.7 & 20 \\
\hline
\end{tabular}

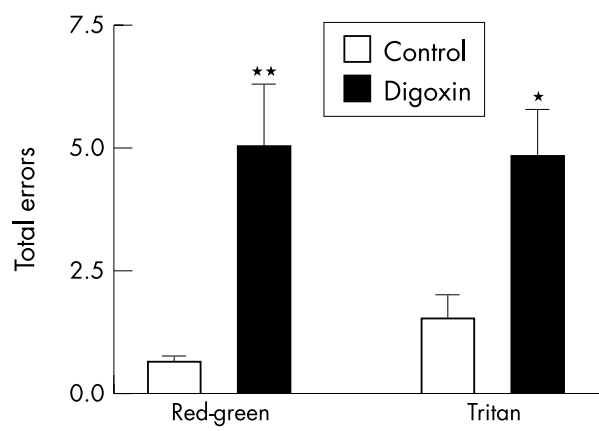

Figure 1 Histogram showing the total red-green and total tritan error scores for controls and patients receiving digoxin therapy. The differences are statistically significant ${ }^{*} p<0.05,{ }^{* *} p<0.01$ (unpaired $t$ test)

Although tritan errors were common in controls, these defects were typically only slight or occasionally moderate (Table 2 ). By contrast, approximately $20 \%$ of subjects in the digoxin group showed a severe tritan defect (Table 2). Figure 1 shows the mean number of red-green and tritan errors recorded in control and digoxin groups. These differences were statistically significant. However, there was no correlation between serum digoxin concentration and the number of red-green errors $\left(r^{2}=0.0009, \mathrm{p}=0.87\right)$, tritan errors $\left(r^{2}=0.0175, \mathrm{p}=\right.$

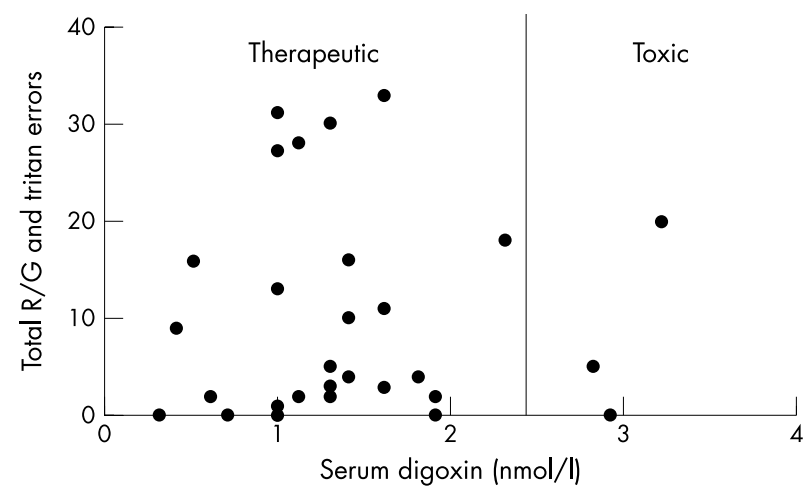

Figure 2 Graph compairing serum digoxin levels with combined error scores for red-green $(R / G)$ and tritan tests. The mean serum digoxin level $=1.4(S D 0.7) \mathrm{nmol} / \mathrm{l}$.
A

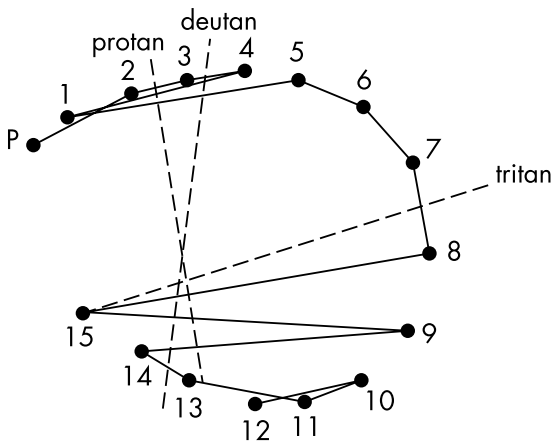

B

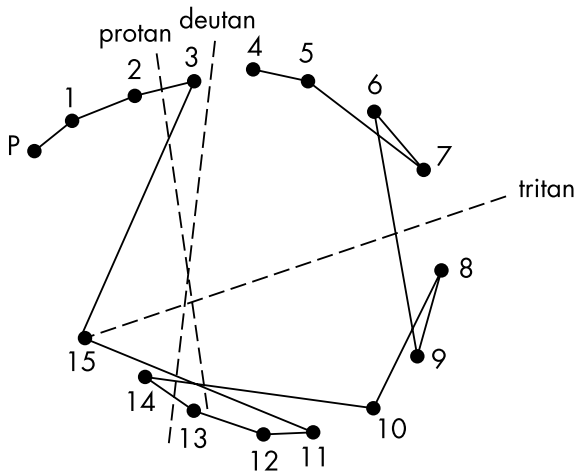

Figure 3 Farnsworth D15 panel from patients taking digitalis showing (A) tritan confusion errors, (B) poor overall hue discrimination.

$0.49)$ or total errors $\left(r^{2}=0.001, \mathrm{p}=0.67\right)$ (Fig 2$)$. Similarly, there was no correlation between the total number of errors and duration of treatment $\left(r^{2}=0.003, \mathrm{p}=0.83\right)$.

\section{Farnsworth D15 panel}

Using the D15 panel, $26.7 \%$ of the digoxin group showing characteristic tritan confusion errors, with 30\% showing an overall poor hue discrimination (Fig 3). No patient showed confusions along the deutan or protan red-green axes. Although control subjects commonly made non-specific arrangement errors, there were no errors along the tritan confusion axis.

\section{DISCUSSION}

Simple screening tests for colour deficiency revealed a high incidence of colour vision impairment in a population of elderly hospitalised patients on maintenance digoxin therapy compared to an age matched control group of hospital inpatients. None of the patients reported any subjective alteration of colour perception. Although $10 \%$ of patients were found to have a serum drug concentration of $>2.6 \mathrm{nmol} / \mathrm{l}$, the mean serum digoxin level for the group was in the middle of the therapeutic range and no patient had clinically defined digoxin toxicity. Both red-green and tritan errors were identified. Slight to moderate red-green impairment was found in approximately $20-30 \%$ of patients, and approximately $20 \%$ showed a severe tritan deficiency. These data suggest that a subclinical impairment in visual function can occur even at therapeutic doses of digoxin. There have been several case reports in the literature of overt visual disturbance-for example, photopsia and reduced acuity, in patients with blood digitalis levels within the therapeutic range. ${ }^{14-16}$ In all cases discontinuation of therapy was followed by complete resolution of symptoms. The reasons for the eye's susceptibility to the untoward effects of digitalis are not fully understood. There is evidence that the retina is the primary site of drug toxicity. ${ }^{17-19}$ Several retinal cells express digitalis sensitive isoforms of sodium-potassium ATPase $\left(\mathrm{Na}^{+} \mathrm{K}^{+}\right.$ATPase $)$- for 
example, photoreceptors, Müller cells, and the retinal pigment epithelium. ${ }^{2021}$ Clinical electroretinography and in vitro cell studies have shown that toxic levels of digoxin lead to rod and cone dysfunction, with cones being affected to a greater extent. ${ }^{18} 19$ These effects were reversed following dose reduction or cessation of therapy.

All the patients in the present study were elderly, and advanced age appears to be a contributory factor in general for drug toxicity, including for digoxin. ${ }^{152}$ The basis for the increased susceptibility to the toxic effects of digitalis in the elderly is unclear, although it may be the consequence of altered renal function, electrolyte disturbances, or changes in the density or character of the drug receptor. The compromised vascular status of the digoxin treated cohort may have also contributed to the observed disturbance in colour vision.

It has been suggested that the effects of digoxin on colour vision may be continuous, commencing with a slight impairment of hue discrimination and progressing initially to a tritan defect, and then to a red-green deficiency as toxicity increases. ${ }^{11}$ The colour vision defect most commonly seen in the present study was in the tritan axis. It is not clear whether these defects reflect a particular vulnerability of the short wave (S) cone pathway to digoxin or the lower density of $S$ cones. Advanced age is known to adversely affect blue-yellow discrimination as a result of reduced transmission of short wavelengths of light through the ocular media. ${ }^{23}$ Slight or moderate tritan errors were common in age matched controls, however severe defects were only observed in patients taking digoxin. The finding of red-green defects in patients taking digitalis in the absence of toxicity was surprising, as red-green deficiency has previously been reported only in severe intoxication. ${ }^{91012}$

A number of previous studies have concluded that formal colour vision testing can be used to screen for digoxin toxicity. Using the FM 100 hue test, a positive correlation has been found between the serum digoxin concentration and the degree of colour deficiency. ${ }^{811}{ }^{13}$ However, the test battery used in the present study found no correlation between the number of red-green or tritan errors and the serum drug level. Moreover, the high incidence of colour vision impairment in patients without toxicity would suggest that routine colour vision screening would not be a reliable indicator of toxicity.

In summary, elderly patients receiving maintenance digoxin therapy showed a high incidence of colour vision impairment. Disturbances in both the tritan and red-green axes were present, in the absence of a subjective alteration of colour perception. By contrast with previous studies on younger populations of patients taking digitalis, no correlation was found between colour vision loss and serum drug concentration. These findings suggest that routine colour vision testing in elderly patients receiving digoxin would have limited value for the detection of drug toxicity.

\section{ACKNOWLEDGEMENT}

The authors thank Dr Mitchell-Heggs, consultant physician, Epsom General Hospital for permission to examine patients in his care.

\section{Authors' affiliations}

J G Lawrenson, C Kelly, J Birch, Applied Vision Research Centre, Department of Optometry and Visual Science, City University, London ECIV OHB, UK

A L Lawrenson, Epsom General Hospital, Dorking Road, Epsom KTI 8 7EG, UK

Correspondence to: Dr J G Lawrenson, Department of Optometry and Visual Science, City University, London EC1V OHB, UK;

J.G.Lawrenson@city.ac.uk

Accepted for publication 12 June 2002

\section{REFERENCES}

1 The Digitalis Investigation Group. The effect of digoxin on mortality and morbidity in patients with heart failure. $N$ Engl J Med 1997;336:525-33.

2 Kelly RA, Smith TW. Recognition and management of digitalis toxicity Am J Cardiol 1992:69:108G-18G.

3 Beller GA, Smith TW, Abelmann WH, et al. Digitalis intoxication. A prospective clinical study with serum level correlations. N Engl J Med 1971;284:989-97.

4 Williamson KM, Thrasher KA, Fulton KB, et al. Digoxin toxicity: an evaluation in current clinical practice. Arch Intern Med 1998:158:2444-9

5 Goldstein RL, Stanton BA, Lipson M. Clinical utility of serum digoxin level tests in hospitalized elderly patients. Arch Phys Med Rehabil 1986;67:34-7

6 Fraufelder FT, Fraunfelder FW. Drug-induced ocular side effects. 5th ed. Boston: Butterworth-Heinemann, 2001.

7 Storstein O, Hansteen V, Hatle L, et al. Studies on digitalis. XIII. A prospective study of 649 patients on maintenance treatment with digitoxin. Am Heart J 1977;93:434-43

8 Rietbrock N, Alken RG. Color vision deficiencies: a common sign of intoxication in chronically digoxin-treated patients. J Cardiovasc Pharmacol 1980;2:93-9.

9 Lely $\mathbf{A H}$, van Enter $\mathrm{CH}$. Large-scale digitoxin intoxication. $\mathrm{BM}$ 1970;3:737-40.

10 Manninen V. Impaired colour vision in diagnosis of digitalis intoxication (letter). BM 1974;4:653-4.

11 Aronson JK, Ford AR. The use of colour vision measurement in the diagnosis of digoxin toxicity. Q J Med 1980;49:273-82.

12 LeSage JM, Chuman MA. Color vision tests to identify elevated digoxin levels. Res Nurs Health 1986:9:171-7.

13 Haustein KO, Schmidt C. Differences in color discrimination between three cardioactive glycosides. Int J Clin Pharmacol Ther Toxicol 1988;26:517-20.

14 Hobley A, Lawrenson J. Ocular adverse effects to the therapeutic administration of digoxin. Ophthalmic Physiol Opt 1991;11:391-3.

15 Butler VP Jr, Odel JG, Rath E, et al. Digitalis-induced visual disturbances with therapeutic serum digitalis concentrations. Ann Intern Med 1995; 123:676-80.

16 Wolin MJ. Digoxin visual toxicity with therapeutic blood levels of digoxin. Am J Ophthalmol 1998; 125:406-7.

17 Binnion PF, Frazer G. ( $\left.{ }^{3} \mathrm{H}\right)$ Digoxin in the optic tract in digoxin intoxication. J Cardiovasc Pharmacol 1980;2:699-706.

18 Weleber RG, Shults WT. Digoxin retinal toxicity. Clinical and electrophysiological evaluation of a cone dysfunction syndrome. Arch Ophthalmol 1981;99:1568-72.

19 Madreperla SA, Johnson MA, Nakatani K. Electrophysiologic and electroretinographic evidence for photoreceptor dysfunction as a toxic effect of digoxin. Arch Ophthalmol 1994:112:807-12.

20 Schneider B. Na+ $\mathrm{K}^{+}$-ATPase isoforms in the retina. Int Rev Cytol 1992;133:151-85.

21 Burke JM, McKay BS. In vitro aging of bovine and human retinal pigment epithelium: number and activity of the $\mathrm{Na} / \mathrm{K}$ ATPase pump. Exp Eye Res 1993;57:51-7.

22 Tumer N, Scarpace PJ, Lowenthal DT. Geriatric pharmacology: basic and clinical considerations. Annu Rev Pharmacol Toxicol 1992;32:271-302.

23 King-Smith PE. In: Foster DH, ed. Inherited and acquired colour vision deficiencies: fundamental aspects and clinical studies. Basingstoke, Hants: Macmillan Press, 1991:38-55. 